\title{
PENDIDIKAN AGAMA ISLAM BAGI ANAK TUNAGRAHITA DI SEKOLAH LUAR BIASA YAYASAN PEMBINAAN ANAK CACAT SEMARANG
}

\author{
Sukijan \\ Universitas Islam Sultan Agung Semarang \\ sukijan@gmail.com
}

\begin{abstract}
This study aims to know and explain; 1) implementation of Islamic religious education for mental retardation children in Extraordinary school C YPAC Semarang; and 2) explain the implications of the implementation of Islamic religious education for mental retardation children in Extraordinary school $C$ YPAC Semarang. This research is a qualitative research type of field research by taking the background of Special School C Foundation for Disabled Children Development Semarang. Mental retardation children are entitled to a religious education worthy in accordance with their respective religions. In this case, Muslim children are given Islamic religious education services to instill Islamic aqidah correctly. Implementation of Islamic education can provide a positive implication for the mental retardation childrens, they can better understand the theory and practice of Islamic religion well. With the knowledge he possesses, he will realize that Allah is Almighty to his creation, so that the mental retardation children are not protracted bemoaning their deficient circumstances. They can be well aware of the situation and can provide stability to the mental.
\end{abstract}

Key Word : Islamic Religious Education, Mentally Disabled, SLB

\begin{abstract}
Abstrak
Penelitian ini bertujuan untuk mengetahui dan menjelaskan; 1) pelaksanaan pendidikan agama Islam bagi anak tunagrahita di SLB C YPAC Semarang; dan 2) menjelaskan implikasi pelaksanaan pendidikan agama Islam pada anak tunagrahita di SLB C YPAC Semarang.Penelitian ini merupakan penelitian kualitatif jenis penelitian lapangan dengan mengambil latar Sekolah Luar Biasa C Yayasan Pembinaan Anak Cacat Semarang.Anak tunagrahita berhak mendapatkan pendidikan agama dengan layak sesuai dengan agamanya masing-masing.Dalam hal ini, anak-anak yang beragama Islam diberi pelayanan pendidikan agama Islam untuk menanamkan akidah Islamiyah dengan benar.Pelaksanaan pendidikan agama Islam ini dapat memberikan implikasi yang positif terhadap anak tunagrahita, mereka bisa lebih memahami teori dan praktik agama Islam dengan baik.Dengan pengetahuan yang dimilikinya, dia akan menyadari bahwa Allah Maha Kuasa terhadap ciptaannya, sehingga anak-anak tunagrahita tidak berlarutlarut meratapi keadaannya yang memiliki kekurangan.Mereka bisa menyadari dengan baik mengenai keadaannya dan bisa memberikan kestabilan pada mentalnya.
\end{abstract}

Kata Kunci: Pendidikan Agama Islam, Sekolah Luar Biasa, Tunagrahita, SLB 


\section{A. PENDAHULUAN}

Penelitian mengenai pendidikan agama Islam di Indonesia menjadi tema klasik skaligus tema kontemporer, dikatakan tema klasik karena penelitian mengenai pendidikan agama Islam telah banyak dilakukan oleh para peneliti terdahulu, baik para mahasiswa maupun dosen. Jika melihat hasil penelitian ini, maka akan ditemukan bermacam-macam judul dan pembahasan yang kemungkinan sama ataupun berbeda. Menumpuknya hasil penelitian mengenai pendidikan agama Islam, seolah-olah penelitian ini tidak menarik lagi, bahkan ada yang mengatakan kehabisan objek.

Kendati demikian, pendidikan agama Islam juga dikatakan tema penelitian kontemporer, karena pendidikan agama Islam saat ini banyak dihadapkan dengan berbagai objek baru, baik di sekolah dasar, menengah, maupun perguruan tinggi. Persoalan-persoalan baru ini tentunya menuntut inovasi pendidikan agama Islam yang berada di lembaga pendidikan.Inovasiinovasi di setiap lembaga pendidikan tentunya berbeda sesuai dengan kebutuhan yang ada, inilah yang terus menjadikan pendidikan agama Islam tetap terus menarik untuk diteliti. Untuk melakukan perubahan fundamental agar dapat menghasilkan sumber daya manusia Islami yang bermutu maka lembaga pendidikan seyogyanya merevitalisasi peran lembaga pendidikan supaya mampu berperan secara optimal dalam mewujudkan academic excellence for education, for industrial relevance, for contribution for new knowledge, dan for empowerment ${ }^{1}$.

Pembahasan pendidikan agama Islam akan terlihat menarik jika direlevansikan dengan tema-tema baru kontemporer pendidikan. Dalam penelitian ini, penulis merelevansikan antara pendidikan agama Islam dengan anak berkebutuhan khusus yang tunagrahita. Anak berkebutuhan khusus merupakan salah satu kategori peserta didik yang memiliki kekurangan pada fisik dan mentalnya.Anak berkebutuhan khusus lebih rinci dapat dikategorikan menjadi beberapa bagian, yaitu tunagrahita, tunarungu, tuna netra, autis, dan tuna daksa, yang kesemuanya berhak mendapatkan pendidikan.

Istilah anak tunagrahita merupakan istilah lain dari retardasi mental (mentalretardation). Menurut Martasuta, "Tunagrahita adalah anak yang secara nyata mengalami hambatan dan keterbelakangan perkembangan mental intelektual."2Atau lebih singkatnya istilah tunagrahita digunakan untuk menyebut anak yang mempunyai kemampuan intelektual di bawah rata-rata, jadi istilah terasebut menjadi ciri khas bagi anak yang memiliki kemampuan rendah.

Pendapat yang hampir sama dikemukakan oleh Santrock, bahwa retardasi mental atau tunagrahita merupakan

1 M. Ihsan Dacholfany, Inisiasi Strategi Manajemen Lembaga Pendidikan Islam Dalam Meningkatkan Mutu Sumber Daya Manusia Islami di Indonesia Dalam Menghadapi Era Globalisasi, Jurnal At-Tajdid, Volume. 1, No. 1 Januari-Juni 2017, h. 2.

${ }^{2}$ U. D. Martasuta, Mengenal Peserta Didik yang Mengalami GangguanMental, Makalah Seminar (Jakarta: UNJ, 2001), h. 54.

191 
kondisi yang dialami anak sebelum menginjak usia 18 tahun. Hal ini ditandai dengan rendahnya kecerdasan atau IQ di bawah 70 dan sulit beradaptasi dengan kehidupan sehari-hari. IQ rendah dan ketidakmampuan beradapatasi yang rendah ini biasanya tampak sejak kanak-kanak, dan tidak tampak pada periode normal, selain itu, keadaan ini bukan disebabkan oleh kecelakaan atau penyakit atau cedera otak. ${ }^{3}$ Berdasarkan penjelasan Santrock tersebut, maka tungrahita dapat dibatasi dengan tiga hal, yaitu munculnya gangguan tersebut sebelum usia 18 tahun, IQ yang dimiliki di bawah 70, tidak disebabkan oleh kecelakaan, penyakit maupun cedera otak.

Berdasarkan deskripsi Santrock tersebut menunjukkan bahwa anak tunagrahita membutuhkan penanganan secara khusus untuk meningkatkan kecerdasan IQ nya, baik dalam bidang agama maupun umum. Jalan yang ditempuh ini bisa dilakukan melalui penyelenggaraan pendidikan bagi anak tunagrahita. Lembaga pendidikan bisa dijadikan alternatif yang kuat, karena melalui hal ini anak-anak tunagrahita bisa mendapatkan banyak pengetahuan dan pelatihan untuk meningkatkan IQ nya.

Kebutuhan terhadap pengetahuan agama Islam bagi anak tunagrahita bukanlah kebutuhan skunder, tetapi kebutuhan primer, sekalipun IQ nya rendah, anak tunagrahita memiliki hak untuk mendapatkan pendidikan agama Islam, melalui pendidikan agama Islamlah anak tunagrahita dapat mengetahui kewajiban dirinya sebagai

${ }^{3}$ J. W. Santrock, Psikologi Pendidikan,terj. T. Wibowo,Edisi II, Vol. 1. Jakarta: Kencana, 2007, h. 224. seorang muslim di dunia ini, baik shalat, zakat, puasa, maupun naik haji, untuk mendapatkan pendidikan agama Islam, maka anak-tunagrahita harus masuk di lembaga pendidikan formal.

Secara teori dan kebijakan, pemerintah Indonesia sangat mendukung diadakannya lembaga pendidikan bagi penyandang disabilitas.Namun secara praktiknya, lembaga-lembaga pendidikan di Indonesia belum sepenuhnya mempersiapkan diri untuk memberikan fasilitas pendidikan bagi anak-anak tunagrahita.Tenaga pendidik dan sarana prasarananya belum sepenuhnya tersedia, sehingga banyak anak-anak tunagrahita yang tidak mendapatkan fasilitas pendidikan seutuhnya.

Selain itu, persoalan yang sangat mencekam secara eksternal bagi anak tunagrahita adalah kurang pahamnya masyarakat mengenai pendidikan anak disabilitas, sehingga memunculkan stigma negatif dari masyarakat.Tidak sedikit masyarakat yang berpendapat bahwa anak penyandang disabilitas tidak perlu mengenyam pendidikan.Dunia pendidikan hanya akan menyusahkan dirinya, terlebih orang-orang yang ada di sekitarnya.Stigmastigma ini banyak memunculkan wacana negatif pula bagi anak, sehingga mereka minder dan malu untuk sekolah.Inilah yang menyebabkan anak tunagrahita berpendidikan rendah dan tidak menunjukkan peningkatan apapun.

Padahal anak tunagrahita seperti anak normal lainnya, yang membutuhkan perhatian dan pendidikan yang layak.Hanya saja, ada kelebihan yang membedakan mereka. Anak tunagrahita tidak selalu anak 
yang lamban belajar, akan tetapi juga anak yang kecepatan menyerap ilmu yang diberikan guru lebih cepat dari anak normal lainnya. Anak tunagrahita tidak selalu anak yang kekurangan secara fisik, akan tetapi anak yang fisiknya normal dengan kekurangan yang ada. Anak tersebut bisa saja mengalami disleksia (kesulitan membaca dan menulis), susahberkonsentrasi dan hiperaktif.

Indonesia merupakan negara hukum telah menjamin pendidikan setiap warganya tanpa terkecuali.Baik mereka yang menderita cacat sekalipun.Kenyataan ini secara hukum dan aturan Indonesia sesuai dengan apa yang diamanahkan oleh UU No. 20 Tahun 2003 tentang Sistem Pendidikan Nasional pasal 5 ayat 2 bahwa warga negara yang memiliki kelainan fisik emosional, mental, intelektual, dan sosial berhak memperoleh pendidikan khusus.Melalui undang-undang ini, maka anak tunagrahita bisa mendapatkan jaminan pendidikan yang layak di lembaga formal.

Di Indonesia jumlah lembaga pendidikan mencapai ribuan, baik yang Islam maupun yang umum. Namun sekolah yang khusus bagi anak berkebutuhan khusus bisa dihitunng di setiap provinsinya.Sekolah di Jakarta ada SLB Negeri 7, SLB Nusantara, dan SLB/B Pangudi Luhur Kebon Jeruk.Sedangkan di Semarang ada SLB Negeri Semarang, SLB B Swadaya, dan SLB C YPAC.Kemudian di Surabaya ada SLB Putra Mandiri Surabaya, SLB/C Aditama, dan SLB BC Optimal.

Salah satu sekolah yang sudah menyiapkan diri dan telah mendidikan anakanak luar biasa ialah Sekolah Luar Biasa (SLB) C YPAC Semarang. Sekolah ini berada di bawah naungan Yayasan Pembinaan Anak Cacat (selanjutnya disebut YPAC). ${ }^{4}$ Kemudian YPAC Semarang mendirikan SLB untuk ABK, diantaranya adalah SLB C untuk membina anak tunagrahita.Di sekolah ini, anak-anak tunagrahita diberikan pendididikan agama Islam dan pendidikan umum.

Pendidikan agama Islam di SLB C bagi tunagrahita bukan sekadar menyampaikan materi, memaksakan kehendak guru, mengejar target kurikulum, dan menyelesaikan bahan ajar yang kadang tidak fungsional terhadap kebutuhan anak tunagrahita.SLB $\mathrm{C}$ ini secara khusus membina anak-anak yang tunagrahita, baik secara mental maupun pengetahuan. Pendidikan agama Islam diajarkan kepada anak-anak tunagrahita dengan intens, baik dari segi teorinya maupun praktiknya. Mengajarkan agama pada anak yang memiliki kelainan, keterbatasan kemampuan dan kecacatan tidak semudah mengajar anak-anak normal. Pendidikan agama Islam di sini memerlukan metode, pendekatan, strategi, dan lain sebagainya untuk bisa memahamkan mereka.

Luddin mengatakan bahwa, "Pembelajaran untuk tunagrahita, hendaknya lebih diarahkan pada membangun kejiwaannya yang labil, kepercayaan diri yang hilang, dan memberikan layanan psikoterapi untuk meluruskan tingkah laku yang tidak tepat sebagai dampak keterbatasan dan kecacatan

\footnotetext{
${ }^{4}$ http://ypac-nasional.org/sejarah-ypac/., diakses pada tanggal 11 februari 2017. 
yang disandangnya". ${ }^{5}$ Namun Mangungsong memberikan penegasan bahwa tidak ada satupun strategi, metode, atau pendekatan serta jenis pendidikan yang dapat memberikan pelayanan-pelayanan pendidikan untuk semua masalah yang berbeda-beda. Dengan demikian juga tidak mengherankan jika para guru yang kreatif memiliki berbagai strategi, metode, dan tata lingkungan dalam upaya memberi setiap anak pendidikan umum yang layak. ${ }^{6}$ Dengan demikian, pendidikan agama Islam yang berada di SLB C memiliki fungsi ganda, yaitu memberikan pengetahuan agama Islam, membangun kejiwaan anak, dan membimbing anak mempraktikkan berbagai kegiatan ibadah dalam Islam.

Berdasarkan latar belakang yang telah penulis paparkan di atas, maka rumusan masalah dalam penelitian ini ialah:

1. Bagaimana pelaksanaan pendidikan agama Islam bagi anak tunagrahita di SLB C YPAC Semarang?

2. Bagaimana implikasi pendidikan agama Islam terhadap pemahaman agama anak tunagrahita di SDLB C YPAC Semarang?

\section{B. METODOLOGI PENELITIAN}

Penelitian yang dilakukan ini adalah penelitian lapangan

(field research).Menurut Moleong, dalam penelitian kualitatif field research memiliki pendekatan yang luas.Bahkan, dapat katakan

${ }^{5}$ A.B.M Luddin, Dasar-Dasar Konseling Tinjauan Teori dan Praktik(Bandung: Cipta Pustaka Media, 2010), h. 80.

${ }^{6}$ Frieda Mangunsong dkk., Psikologi dan Pendidikan Anak Luar Biasa(Jakarta: Lembaga Pengembangan Sarana Pengukuran dan Pendidikan Psikologi (LPSP3) UI, 1998), h. 13. sebagai metode untuk mengumpulkan data kualitatif. ${ }^{7}$ Hal penting dalam penelitian ini adalah peneliti berangkat ke 'lapangan' untuk melakukanobervasi/pengamatan terhadap suatu fenomenasecara alami.Maka Mulyana menyamakan field research ini dengan penelitian naturalistik.Artinya peneliti mengamati dan mengumpulkan data sesuai dengan apa yang ada di lapangan atau dengan kata lain Moleong menyebutnya "insitu" (di situ). ${ }^{8}$

Lebih lanjut Mulyana menjelaskan bahwa penelitian lapangan atau field research merujuk pada metode-metode penelitian yang kadang disebut participant observation (pengamatan berperan-serta), direct observation (pengamatan langsung), dancase studies (studi kasus). Menurut Mulyana, ${ }^{9}$ studi kasus adalah uraian atau penjelesan komprehensif mengenai berbagai aspek seseorang atau individu, suatu kelompok, suatu organisasi (komunitas), suatu program, atau suatu situasi sosial. studi kasus pada penelitian ini adalah kelompok, yaitu dua orang guru PAI.

Adapun pendekatan yang digunakan peneliti adalah pendekatan kualitatif. Sehubungan pendekatan kualitatif merujuk pada kualitas alamiah, maka berbeda dengan pendekatan kuantitatif yang diperhitungkan dengan kuantum atau jumlah. ${ }^{10}$ Jadi, penelitian ini tidak mengadakan perhitungan.

${ }^{7}$ L. J.Moleong, Metode Penelitian Kualitatif, (Bandung: PT. Remaja Rosdakarya, 2016), h. 26.

${ }^{8}$ Deddy Mulyana, Metodologi Penelitian Kualitatif(Bandung: PT Remaja Rosdakarya, 2013), h. 160 .

${ }^{9}$ Ibid., h. 201.

${ }^{10}$ L. J. Moleong, Metode Penelitian Kualitatif..., h. 5. 
C. PEMBAHASAN

1. Sejarah SLB C YPAC Semarang

Berdasarkan studi dokumentasi, SLB.

C/C1 YPAC Semarang berdiri dibawah YPAC yang semula hanya menangani anakanak cacat fisik (SLB.Dl/D). Mengingat perkembangan anak tunagrahita semakin banyak dan YPAC Semarang merupakan sekolah tempat orang mencari informasi, maka pada tahun 1981 pengurus Yayasan merasa terpanggil untuk membuka SLB C/C1 memanfaatkan gedung pada siang hari. ${ }^{11}$

\section{Visi dan Misi SLB C YPAC Semarang}

YPAC Semarang didirikan dengan maksud dan tujuan yaitu di bidang sosial dan kemanusiaan, terutama dalam upaya ke arah tercapainya kesejahteraan anak dengan kecacatan pada khususnya dan kesejahteraan masyarakat pada umumnya.

Visi dari SLB C YPAC Semarang ialah "Terwujudnya pelayang yang optimal terhadap anak berkebutuhan khusus agar memiliki budi pekerti yang luhur, berprestasi, terampil, dan mandiri.Sedangkan misi dari SLB C YPAC adalah sebagai berikut: ${ }^{12}$

a. Menanamkan keyakinan/aqidah melalui pengamalan ajaran agama.

b. Mengembangkan pengetahuan dan teknologi, olahraga, seni, dan budaya

\footnotetext{
${ }^{11}$ http://www.ypac-semarang.org/index.php? pilih=hal\&id=13 diakses pada hari jumat, tanggal 17 Februari 2017 Pukul 15.05.

${ }^{12}$ dari Website SLB C YPAC Semarang yang diakses 17 Januari 2017
}

sesuai dengan bakat, minat, dan protensi siswa.

c. Melaksanakan pembelajaran dan bimbingan secara produktif, aktif, kreatif, efektif, dan menyenangkan.

d. Meningkatkan keterampilan mengurus diri.

\section{Pelaksanaan Pendidikan Agama Islam Bagi Anak Tunagrahita di SLB C YPAC Semarang}

Pendidikan Agama Islam di SLB C YPAC Semarang didasarkan pada tiga landasan, yaitu landasan yuridis, landasan religius, dan landasan psikologis.

Secara yuridis, Pendidikan Agama Islam di SLB C YPAC Semarang didasarkan pada:

a. Undang-Undang Nomor 20 Tahun 2003 Tentang Sistem Pendidikan Nasional Pasal 5 Ayat 2 yang menyatakan bahwa "Warga negara yang memiliki kelainanfisik, emosional, mental, intelektual, dan/atau sosial berhak memperoleh pendidikan khusus."

b. Undang-Undang Nomor 20 Tahun 2003 Tentang Sistem Pendidikan Nasional Pasal 12 Ayat 1 butir (a) yang menyatakan bahwa, "Setiap pesertadidikpadasetiap satuan pendidikan berhak mendapatka npendidikan agama sesuai dengan agama yang dianutnya dan diajarkan oleh pendidik yang seagama". Undang-Undang Nomor 20 Tahun 2003 Tentang Sistem Pendidikan Nasional Pasal 12 Ayat 1 butir (b) yang menyatakan bahwa, "Setiap peserta didik pada setiaps atuan pendidikan berhak mendapatkan pelayanan pendidikan 
sesuai dengan bakat, mint, dan kemampuannya."

Sedangkan secara religius, Pendidikan Agama Islam di SLB C YPAC Semarang didasarkan pada fiman Allah dalam AlQur'an Surat Al-Mulk Ayat 2 yang berbunyi:

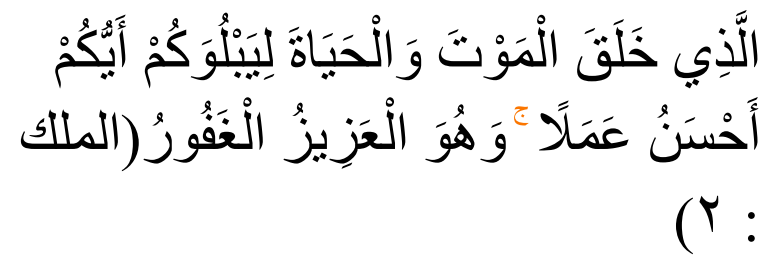

Artinya:

"Yang menjadikan mati dan hidup, supaya Dia menguji kamu, siapa di antara kamu yang lebih baik amalnya,dan Dia Maha Perkasa lagi Maha Pengampun." (QS. AlMulk [67]: 2)

Adapun secara psikologis, Pendidikan Agama Islam di SLB C YPAC Semarang didasarkan padakebutuhan anak dalam hal ibadah. Setiap manusia harus beribadah. Sedangkan ibadah senantiasa terkait dengan syarat, rukun, sunnah, dan lain sebagainya. Sekian hal yang terkait dengan tersebut tidak dapat diketahui anak tanpa melalui proses pendidikan.

\section{a. Tujuan Pendidikan Agama Islam}

Secara umum, PAI di SLB C YPAC Semarang ini bertujuan supaya peserta didik dapat beribadah secara mandiri, baik di rumah maupun di sekolah. ${ }^{13}$ Sedangkan tujuan instruksional Pendidikan Agama Islam di SLB C YPAC Semarang sesuai dengan tingkat atau jenjang pendidikannya

\footnotetext{
${ }^{13}$ Wawancara dengan Syamsul Hidayat sebagai Guru Pendidikan Agama Islam di SLB C YPAC Semarang pada 14 Februari 2017, pukul 16.00.
}

masing-masing sebagaimana instruksi yang tertuang dalam Kompetensi Inti dan Kompetensi Dasar (KI-KD) 2016. Anak tunagrahita yang ada pada tingkat Sekolah Dasar Luar Biasa (SDLB) diharapkan "Memiliki perilaku jujur, disiplin tanggung jawab, santun, peduli,dan percaya diri dalam berinteraksi dengan keluarga, teman, dan guru" (KI-KD SDLB, 2016: 2).

Sedangkan tujuan Instruksional PAI bagi anak tunagrahita tingkat Sekolah Menengah Pertama Luar Biasa (SMPLB) betujuan supaya mereka mampu "Menghargai dan menghayatiperilaku jujur, disiplin tanggung jawab, santun, peduli (toleransi, gotong royong), santun dan percaya diri dalam berinteraksi secara efektif dengan lingkungan sosial dan alam dalam jagkauan pergaulan dan keberadaannya" (KI-KD SMPLB, 2016: 2).

Adapun untuk tingkat Sekolah Menengah Atas Luar Biasa (SMALB) memiliki tujuan supaya anak tunagrahita mampu "Menghargai dan menghayati perilaku jujur, disiplin, tanggungjawab, peduli (toleransi, gotong royong), santun, percaya diri, dalam berinteraksi secara efektif dengan lingkungan sosial dan alam dalam jangkauan pergaulan dan keberadaannya" (KI-KD SMALB, 2016: 2).

\section{b. Subjek dan Objek Pendidikan Agama Islam}

Meskipun SLB C dan SLB D bernaung pada yayasan yang sama, yaitu YPAC Semarang, namun keduanya memiliki Guru PAI (Selanjutnya disebut GPAI) yang berbeda. Seluruh GPAI di SLB berjumlah empat orang.Dua orang guru mengajar PAI di SLB D untuk tunadaksa. Sedangkan dua yang lainnya mengajar PAI 
di SLB C tungrahita.Adapun guru PAI di SLB C adalah Hj. Qomariah, A.Ma.Pd.dan Syamsul Hidayat, S.Pd.I.

$\mathrm{Hj}$. Qomariyah adalah warga Genuk Sari Semarang.Ia seorang Pegawai Negeri Sipil (PNS) di Kementerian Agama (selanjutnya disebut Kemenag). Pengalaman belajar di bidang agama dimulai di Pesantren Al-Fatah Demak yang pada saat itu diasuh oleh Mbah Cholil (Ayahanda dari Dr. KH.Ab. Arief Cholil Dosen FAI UNISSULA). Setelah tujuh tahun menyelesaikan pendidikan pesantren,ia melanjutkan pendidikan guru agama (PGA). Kemudian pada tahun 1984, perempuan berkelahiran 09 Oktober 1959 ini diangkat menjadi PNS. ${ }^{14}$

Pada usia ke-25, ia memulai profesinya sebagai guru di Madrasah Ibtidaiyah Miftahus Sibyan Banjardowo Semarang. Setelah 5 tahun mengajar, kemudian ia dipindah ke Madrasah Hidayatus Syubban Karangroto Semarang. Di madrasah ini, ia hanya mengajar selama dua tahun. Maka pada tahun 1991 sampai 1995 ia kembali lagi ke Madrasah Ibtidaiyah Miftahus Sibyan. Kemudain ia melanjutnya perjuangannya di Madrasah Ibtidaiyah Mirfaul Ulum Gebangsari Semarang sampai tahun 1998. Setelah beberapa kali ia dipindahtempatkan sebagai pengajar, akhirnya pada tahun 2004 ia diperbantukan oleh Kemenag untuk mengajar di SLB C YPAC Semarang sampai sekarang. ${ }^{15}$

\footnotetext{
${ }^{14}$ Wawancara dengan Qomariyah sebagai Guru Pendidikan Agama Islam pada tanggal 19 Februari 2017 pukul 08.30.

${ }^{15}$ Wawancara dengan Qomariyah sebagaiGuru Pendidikan Agama Islam pada tanggal 19 Februari 2017 pukul 08.30.
}

Pada tahun 2004, Kemenag memberikan bantuan dua orang GPAI yang berstatus PNS.Pada perkembangannya, salah satu guru tersebut mengajukan permohonan pindah.Sedangkan Qomariyah bertahan sampai hari ini.Oleh karena itu, perempuan yang akrab disapa "Bu Qom" ini mengajar PAI sebanyak empat puluh delapan jam selama satu minggu.Perjuangan yang besar ini dilakukan dengan istiqomah selama 10 tahun.Keterbatasan guru PAI di yayasan ini, membuat YPAC Semarang mengambil keputusan untuk mengangkat guru PAI.

Syamsul Hidayat adalah warga Sembungharjo Semarang.Pria berkelahiran 22 Desember 1990 ini menyelesaikan strata satu di Fakultas Agama Islam Jurusan Tarbiyah Universitas Islam Sultan Agung Semarang pada tahun 2014.Guru PAI yang akrab disapa "Pak Syam" ini memiliki pengalaman mengajar mulai tahun 2014. Pada tahun 2015 ia bertemu dengan teman akrabnya, Haikal Hakimuddin. Haikal merupakan salah satu putra Bu Qom.Haikal menawari kesempatan mengajar di sekolah dimana tempat ibunya mengajar.Pak Syam meng-iya-kan tawaran tersebut dan mengajukan lamaran ke YPAC Semarang.Melalui rekomendai $\mathrm{Bu}$ Qom, akhirnya Pak Syam diterima menjadi Guru PAI di SLB C YPAC.Iajuga mengajar PAI di SMALB dan SMPLB Kelas VIII dan IX.

\section{c. Materi Pendidikan Agama Islam}

Kurikulum yang digunakan dalam pembelajaran PAI di SLB C YPAC Semarang adalah Kurikulum 2013.Kementerian Pendidikan dan Kebudayaan (selanjutnya disebut Kemendikbud) telah menyusun Kompetensi 
Inti dan Kompetensi Dasar (selanjutnya disebut KI-KD) PAI khusus bagi anak tunagrahita yang disesuaikan dengan Kurikulum 2013.Namun tidak semua tingkatan memiliki kurikulum yang sama. Hal ini sesuai dengan pernyataan Waka Kurikulum SLB C YPAC Semarang, Sri Suparni yang mengatakan bahwa kurikulum yang digunakan untuk SLB C YPAC Semarangadalah Kurikulum 2013, kecuali kelas XII. $^{16}$

Setiap jenjang pendidikan memiliki KI-KD yang berbeda sebagaimana yang disusun oleh Kemendikbud. Materi PAI di SLB C YPAC Semarang diturunkan dari KI-KD PAI 2016 yang ada, yaitu sebagai berikut:

1. Kelas I (Satu)

- Surat Al-Fatihah dan huruf hijaiyah mulai alif sampai dhad.

- Dua kalimah syahadat.

- Doa sebelum dan sesudah belajar.

- Kebersihan lingkungan.

- Kisah teladan Rasulullah Saw.

2. Kelas II (Dua)

- Surat Al-Ikhlas dan huruf hijaiyah mulai tha sampai ya'.

- Iman kepada malaikat.

- Kebersihan diri dan lingkungan.

- Disiplin di kelas, rumah, dan masyarakat.

- Kisah ketulusan dan kesabaran Rasulullah terhadap teman.

3. Kelas III (Tiga)

- Surat An-Nas dan makharijul huruf.

- Bacaan dan gerakan shalat.

${ }^{16}$ Wawancara dengan Sri Suparni sebagai Waka Kuirkulum SLB C pada tanggal 13 Februari 2017 pukul 16.30.
- Mencintai dan meneladani akhlak Rasulullah.

- Cara membersihkan hadas dan najis.

- Kisah teladan Siti Masyithah.

4. Kelas IV (Empat)

- Surat Al-Kautsar dan menyampung dua huruf hijaiyah.

- Iman kepada kitab suci Al-Qur'an.

- Perilaku hidup sehat diri dan lingkungan.

- Hadas besar dan mandi wajib.

- Toleransi beragama.

5. Kelas V (Lima)

- Surat Al-Ma'un

- Perilaku mandiri dalam kehidupan sehari-hari.

- Peduli sosial terhadap sesama.

- Berbagi kepada keluar, teman, dan tetangga.

- Memelihara dan mencurahkan kasih sayang kepada sesama, binatang dan tumbuhan.

6. Kelas VI (Enam)

- Menghargai teman yang berprestasi.

- Sikap rendah hati meminta maaf kepada orang tua, guru, sesama, dan keluarga.

- Perilaku lapang dada dan mudah memaafkan kesalahan orang lain.

- Shalat sunat Idul Fitri dan Idul Adha dengan perbedaan faham dalam keberagaman pemahaman ajaran Islam.

- Cinta damai dalam menghargai berbagai bacaan taubat yang beragam.

7. Kelas VII (Tujuh)

- Surat Adh-Dhuha 
- Peduli lingkungan dan dari siksa kubur.

- Contoh ulet dan sabar dalam bekerja sama meraih tujuan.

- Shalat wajib di awal waktu.

- Contoh sabar, gigih dan ulet Nabi Muhammad Saw. dalam dalam berdakwah.

8. Kelas VIII (Delapan)

- QS. Al-Takatsur.

- Contoh perilaku yang religius mengharapkan nikmat syurga dan menjauhkan diri dari siksa neraka.

- Contoh etika bergaul dengan muhrim dan bukan muhrim sesuai syariat Islam.

- Ibadah Puasa.

- Kisah teladan Nabi Yusuf dan Aisyah.

9. Kelas IX (Sembilan)

- QS. Al-Lahab.

- Contoh perilaku yang menunjukan Allah Maha Kuasa.

- Contoh perilaku patuh, ikhlas dan sabar dalam taat kepada Allah.

- Contoh perilaku dermawan dan mengharapkan pahala ibadah haji dan umroh dan qurban.

- Contoh keteladanan Nabi Ismail dan Nabi Daud as yang dapat diterapkan dalam kehidupan sehari-hari.

10. Kelas X (Sepuluh)

- QS. Al-Hujurat ayat 10.

- Arti sifat Allah Al-'Adl dan AlHakim.

- Manfaat semangat dalam menuntut ilmu.

- Rukun Haji dan umrah
- Kisah perjuangan Rasulullah periode Makkah.

11. Kelas XI (Sebelas)

- Arti QS. Al-Maidah Ayat 32 tentang toleransi.

- Nama-nama Rasulullah yang wajib diimani.

- Syaja'ah dan hikmah beriman kepada hari akhir.

- Pelaksanaan shalat jenazah.

- Kisah perjuangan Rasulullah periode Madinah.

12. Kelas XII (Dua Belas)

- QS. Luqman Ayat 14.

- Pengertian sifat Allah As-Syakut dan Al-Ghafur.

- Kerja keras dalam kehidupan seharihari.

- Ketentuan pernikahan dalam Islam.

- Perkembangan Islam pada masa modern.

Qomariyah dan Hidayat mengatakan bahwa KI-KD untuk anak tunagrahita sebenarnya sudah berbeda dengan KI-KD bagi anak pada umumnya.Meskipun demikian, anak tunagrahita belum dapat mencapainya, karena berbagai macam hambatan yang dimiliki anak tunagrahita.Oleh karena itu, kedua Guru PAI sepakat bahwa materi yang diberikan tetap berdasarkan KI-KD yang ada, namun disesuaikan dengan tingkat kemampuan mereka. ${ }^{17}$

\section{d. Metode Pendidikan Agama Islam}

Metode yang sering digunakan dalam pembelajaran PAI meliputi tiga metode,

${ }^{17}$ Wawancara dengan Qomariyah pada tanggal 19 Februari 2017 pukul 08.30 dan wawancara dengan Syamsul Hidayat pada tanggal 16 Februari 2017 pukul 16.00 . 
yaitu metode ceramah, metode demonstrasi, dan metode menebali. Ketiga metode tersebut selalu digunakan disesuaikan dengan kebutuhan di kelas. Secara lebih rinci bisa dilihat di bawah ini:

\section{e. Metode Ceramah}

Metode ini digunakan untuk menyampaikan materi yang butuh penjelasan banyak. Pada umumnya, anak tungrahita di SLB C YPAC semarang ini tidak suka apabila GPAI menyampaikan materi dengan metode ceramah, khususnya mereka yang sudah pada level SMA. Kebanyakan mereka protes ketika guru menggunakan metode ceramah.Kendati demikian, metode ini masih tetap digunakan dalam menyampaikan materi, karena metode ini poros dari segala metode. ${ }^{18}$

\section{f. Metode Demonstrasi}

Materi-materi yang berupa bacaan atau doa dalam ibadah tidak cukup apabila disampaiakn begitu saja, oleh karena itu GPAI berharap anak tunagrahita dapat melafalkan dan menghafalnya. Sehubungan mereka lemah dalam membaca, maka GPAI membacakan dan meminta siswa untuk menirukan berkali-kali sampai hafal. ${ }^{19}$ Dengan metode ini, anak-anak terlebih dulu diberi contoh dalam melafalkannya, agar anak-anak dapat dengan mudah menirukan hafalan yang diperagakan oleh guru.

\section{g. Metode Menebali}

Menulis adalah salah satu kegemaran anak tunagrahita di SLBC YPAC Semarang,

\footnotetext{
${ }^{18}$ Observasi terhadap kegiatan belajar yang diajar oleh Syamsul Hidayat pada tanggal 15 Februari 2017 pukul 14.00.

${ }^{19}$ Observasi terhadap Qomariyah saat mengajar pada tanggal 13 Februari 2017 pukul 12.30.
}

dibandingkan dengan mendengarkan GPAI mengajar. Namun tidak semua anak tunagrahita memiliki kemampuan menulis yang sama. Di antara mereka ada yang mampu menulis, adapula yang baru bisa menebali, dan yang paling memprihatinkan ada pula yang hanya bisa mencoret-coret buku mereka. Oleh karena itu, guru perlu memakai metode menebali untuk mengembangkan potensi awal yang dimiliki anak-anak. $^{20}$ Adapun Langkah-langkah metode menebali adalah sebagai berikut:

a. Menuliskan materi pada buku tulis siswa dengan menggunakan pensil

b. Siswa diminta untuk menebali dengan bolpoin

c. Guru mengoreksi hasil penebalan

d. Meminta siswa untuk menyesuaikan atau merevisi kembali apabila terdapat kesalahan dalam menebali.

\section{h. Melakukan Pengulangan Secara Berkelanjutan}

Pada saat melaksanakan pembelajaran, GPAI SLB C YPAC Semarang tidak segansegan mengulang kata demi kata secara berkelanjutan . Apabila materi yang diajarkan berupa bacaan-bacaan ibadah, maka guru mengulangi sampai anak tunagrahita mampu menirukan.Karena kesulitan berbicara merupakan satu problematika anak tunagrahita yang tidak mudah untuk ditangani.Apabila materi itu berupa gerakan-gerakan suatu ibadah misalkan wudhu atau shalat - maka guru pun mempraktikan berkali-kali sampai siswa bisa menirukan.Oleh karena itu, GPAI SLB C YPAC Semarang ini melakukan pengulangan secara berkelanjutan.

\footnotetext{
${ }^{20}$ Observasi terhadap Syamsul Hidayat saat mengajar pada tanggal 15 Februari 2017 pukul 14.00.
} 
Pengulangan ini dilakukan dalam satu pertemuan dan bahkan dalam pertemuan lain pun masih dilakukan jika anak tunagrahita belum mampu menirukan.

\section{i. Lingkungan Pendidikan Agama Islam}

Gedung sekolah yang gunakan SLB C YPAC berada dalam satu komplek dengan Gedung Yayasan Pembinaan Anak Cacat (YPAC) Semarang.Gedung ini dimanfaatkan untuk SLB D pada pagi hari mulai pukul 07.00-11.45. Sedangkan SLB C memanfaatkan gedung yang sama pada siang hari mulai pukul 12.45-17.00. Karena pada awalnya YPAC Semarang hanya melayani SLB D untuk tunadaksa. Karena kebutuhan pendidikan anak tunagrahita, maka dibuka SLB C. Sehubungan gedung digunakan terbatas dan kebutuhan pendidikan yang mendesak, maka SLB C diselenggarakan pada siang hari di gedung yang sama.

j. Mushala

Mushala sebagai salah satu lingkungan PAI di SLB C YPAC Semarang memberikan pengalaman tersendiri bagi siswa. Mushala di SLB C YPAC digunakan sebagai tempat praktik siswa dalam mata pelajara agama atau PAI, terutama praktik wudhu dan shalat.Selain itu, mushola di SLB C YPAC juga dimanfaatkan sebagai tempat sentral untuk melaksanakan kegiatan keagamaan seperti memperingari hari besar Islam. $^{21}$

\section{k. Lingkungan Sosial}

Orang tua siswa SLB C YPAC mempunyai perhatian dan sikap yang

${ }^{21}$ Wawancara dengan Qomariyah sebagai guru PAI pada tanggal 19 Februari 2017 pukul 08.30. berbeda terhadap anak mereka. Sebagian besar orang tua siswa SLB C YPAC ini menunggui anaknya sampai selesai sekolah.Selain itu, mereka juga bisa bekerjasama dengan guru PAI dalam memberikan kontrol atau pengawasan terhadap anak-anak mereka ketika di rumah.Salah satu perhatian yang diberikan orang tua terhadap siswa adalah dengan memeriksa hasil belajar siswa di sekolah, misalnya dengan memeriksa hasil catatan mereka.Sehingga ini menjadi motivasi GPAI untuk senantiasa memberikan cacatan kepada siswa.Karena apabila itu tidak dilakukan, maka dapat menimbulkan protes dari orang tua. ${ }^{22}$

\section{l. Pendidik}

SLB C YPAC memiliki 30 guru. Seluruh guru tersebut memiliki karakteristik yang berbeda-beda, baik dari usia, asal-usul, jenis kelamin, agama, dan latar belakang. Meskipun perbedaan di antara mereka tidak dapat dipungkiri, namun kerukunan di antara sesama sangan erat.Solidaritas antar guru di SLB C YPAC sangat kuat.Apabila salah satu guru memiliki hajat atau musibah, maka semua guru bersama-sama menjenguk atau membantu baik secara spiritual maupun material.Solidaritas ini tidak hanya terjadi antar guru, melainkan juga antara guru dan siswa. Anak tunagrahita rata-rata memiliki usia yang pendek. Sehingga sering kali musibah menimpa SLB C YPAC.Setiap kali ada siswa yang meninggal, semua guru pun ikut ta'ziyah. ${ }^{23}$

\footnotetext{
${ }^{22}$ Wawancara dengan Syamsul Hidayat sebagai Guru Pendidikan Agama Islam pada tanggal 16 Februari 2017 pukul 16.00.

${ }^{23}$ Wawancara dengan Syamsul Hidayatsebagai Guru Pendidikan Agama Islam pada tanggal 16 Februari 2017 pukul 16.00.
} 


\section{m. Teman dan Lingkungan Alam}

Anak tunagrahita yang bersekolah ini SLB C ini rata-rata terisolasi ketika di rumah.Syamsul mengatakan bahwa mereka lebih suka masuk sekolah dari pada libur.Hal ini karenakan mereka memiliki banyak teman ketika dikelas.Sedangkan mereka tidak memiliki teman ketika di rumah. ${ }^{24}$ Keberadaan lingkungan sekolah yang banyak mengapresiasi dan memperhatikan dirinya, maka anak-anak tunagrahita lebih nyaman ketika berada di sekolahan.

Selain itu, hal yang membuat betah di sekolah ialah bahwa secara klimatologis, iklim di daerah Semarang sama dengan iklim di daerah lain seperti Demak, Kendal, dan lain-lain. Secara geografis, SLB C berada di tengah perkotaan yang memberikan kemudahan bagi para peserta didik untuk menjangkaunya. Sedangkan keadaan tanahnya normal, artinya bukan tanah yang rawan dengan gempa atau bencana-benca lain yang dapat mengganggu proses pembelajaran.

\section{Implikasi Pendidikan Agama Islam terhadap Pemahaman Agama Anak Tunagrahita}

\section{a. Implikasi secara Teoretis}

Pelaksanaan pendidikan agama Islam di SLB YPAC Semarang dapat berimplikasi secara langsung kepada anak tunagrahita.Pemahaman teoretis mengenai agama Islam merupakan pondasi awal bagi anak-anak tunagrahita untuk mengukuhkan

\footnotetext{
${ }^{24}$ Wawancara dengan Syamsul Hidayat sebagai Guru Pendidikan Agama Islam pada tanggal 16 Februari 2017 pukul 16.00.
}

keimanan dan ketakwaaannya kepada Allah.Melalui beberapa materi dari kelas satu hingga kelas enam dan metode serta pendekatan yang relevan, memberikan pemahaman yang nyata dan lebih dalam kepada mereka.

Pendidikan agama Islam yang telah terlaksana di SLB C YPAC Semarang, bisa berimplikasi terhadap pemahaman mengenai teori-teori yang ada, seperti teori tauhid dan syahadat, kebersihan lingkungan, dan teladan-teladan rasulullah.Selain itu, mereka juga bisa belajar mengenai toleransi beragama dan etika bergaul sesama manusia.Dari sini,anak-anak tunagrahita dapat mengerti betapa Indahnya Islam, yang telah mengatur berbagai hal di dalam kehidupan.Pemahaman anak sekolah dasar mengenai agama Islam dijadikan sebagai pondasi untuk bisa mengembangkan potensi-potensi yang ada di dalam dirinya.

Selanjutnya pendidikan agama Islam ini berimplikasi pada perkambangan mental anak tunagrahita.Adanya pendidikan agama Islam dapat menguatkan mental mereka dalam belajar dan menghadapi berbagai persoalan sosial yang bisa merugikan dirinya.Mereka bisa memahami bahwa Allah merupakan pencipta yang baik bagi dirinya. Tentunya iniakan selalu mendampingi dirinya di dalam kondisi apapun. Sulitnya menerima keadaan menjadi tidak selamanya terjadi, lambat laun mentalnya bias stabildan bisa menerima dengan lapang dada terhadap kondisinya.

Dalam pelaksanaan Implikaasi secara Praktik pada Pendidikan Agama Islam bagi Anak Tunagrahita Lebih Diperhatikan, terdapat kekurangan fasilitas dalam 
memberikan pel ayanan pendidikan agama Islam bagi anak tunagrahita menjadi problem utama yang harus dibenahi.Praktik pendidikan agama Islam di Indonesia bagi anak berkebutuhan khusus, terutama anak tunagrahita bisa dikatakan masih minim.Padahal secara yuridis semua warga Indonesia berhak mendapatkan pendidikan agama sesuai agamanya masing-masing dengan tujuan untuk lebih mengarahkan anak tunagrahita agar lebih mahir dalam praktik beribadah, baik secara privat maupun sosial, oleh karena itu, berawal dari SLB C YPAC Semarang, dapat memberikan stimulus kepada para praktisi pendidikan untuk lebih memperhatikan pelaksanaan pendidikan agama Islam bagi anak tunagrahita.Secara operasional, perhatian terhadap pelaksanaan pendidikan agama Islam bagi anak tunagrahita ini diperluas, sehingga tujuan untuk mencerdaskan anak tunagrahita bisa tercapai dengan maksimal.Pemerataan ini bisa dilakukan melalui dua hal, yaitu sosialisasi dan fasilitasi.Sosialisasi perlu dilakukan oleh semua pihak, terutama praktisi pendidikan agar banyak relawan untuk menjadi pendidik di SLB C YPAC Semarang dan ditempat-tempat lainnya.Sedangkan fasilitasi bisa disediakan dengan baik oleh SLB sendiri ataupun oleh lembaga-lembaga lainnya.

Dengan adanya perhatian terhadap pelaksanaan pendidikan agama Islam ini, maka pelaksanaan pendidikan agama Islam di SLB C YPAC ini bisa menambah sumber daya pendidiknya dan diperbaiki sistemnya.Pendidik agama Islam di SLB C YPAC ini masih minim, sehingga perlu amunisi pendidik-pendidik lain yang memiliki latar belakang pendidikan sesuai dengan bidangnya. Dengan demikian, SLB C YPAC bisa meningkat mutunya danakan membwa peningkatan kecerdasan anak-anak tunagrahita dan mereka bisa terentaskan dari status tunagrahita.

Aadanya Kerjasama Pendidikan Lebih Luas di lembaga tersebut, bagi anak-anak tunagrahita di SLB C YPAC ini tentu sangat membutuhkan sentuhan dari relawanrelawan lainnya untuk mendidik mereka.Maka diperlukan adanya kerjasama pendidikan yang lebih luas, agar para praktisi dan ahli dalam bidang disabilitas bisa berkontribusi di SLB ini.Dengan peningkatan perhatian terhadap pendidikan agama Islam pada SLB C YPAC Semarang, tentu akan memperluas jaringan kerjasama. Perluasan kerjasama ini bisa dengan institusi pemerintah, lembaga-lembaga pendidikan lain, ormas-ormas Islam, dan komunitas yang konsen terhadap disabilitas. Perluasan kerjasama ini bisa memberikan suntikan tenaga, dana, dan sarana yang dibutuhkan dalam pendidikan agama Islam.

Perluasan jaringan kerjasamadengan institusi pemerintah, terutama dengan Kementerian Agama dapat memberikan suntikan khusus dalam menyelesaikan persoalan-persoalan pendidikan agama Islam bagi anak tunagrahita. Begitu juga dengan lembaga-lembaga, ormas-ormas maupun komunitas lainnya, mereka akan membatu pelaksanaan pendidikan agama Islam. Dengan demikian, nasib pendidikan agama Islam anak tunagrahita tetap terjamin. 


\section{KESIMPULAN}

Pendidikan agama Islam tidak hanya diajarkan kepada anak-anak yang normal, tetapi kepada anak-anak yang berkebutuhan khusus.Pelaksanaan pendidikan agama Islam bagi anak berkebutuhan khusus, terutama anak tunagrahita secara konkrit telah dilaksanakan oleh SLB C YPAC Semarang.Sekolah ini memberikan pelayanan pendidikan agama Islam untuk membina pemahaman agama anak-anak tunagrahita.Berdasarkan visi dan misi SLB C YPAC Semarang, maka pendidikan agama Islam bagi anak tunagrahitamutlak harusdilaksanakan.Penanaman akidah Islamiyah yang kukuh bisa terlaksana dengan terlaksananya pendidikan agama Islam dengan baik.Pelaksanaan pendidikan agama Islam yang terlaksana telah menetapkan dasaryang kuat, tujuan yang pasti,kemudian memperhatikanlingkungan, metode, materi dubjek dan objek.

Adapun implikasi pelaksanaan pendidikan agama Islam bagi anak tunagrahita di SLB C Semarang ialah implikasi teoretis dan implikasi secara praktis.Implikasi secara teoretis ialah bahwa pemahaman anak-anak mengenai teori-teori yang ada di agama Islam bisa dipahami dengan baik, sehingga menumbuhkan mental yang stabil.Sedangkan implikasi secara praktis meliputi diperhatikannya pendidikan agama Islam bagi anak tunagrahita dan meluasnya jaringan pendidikan.

Saran bagi peneliti selanjutnya bagi SLB C YPAC Semarang adalah untuk mengidentifikasi tipe anak tunagrahita lebih mendalam di awal peneriman peserta didik baru yang sesuai dengan KI-KD agar guru tidak kehabidan waktu untuk menyesuaikan Rencana Pelaksanaan Pembelajaran (RPP) dengan kemampuan anak tunagrahita.selain itu, SLB C YPAC hendaknya menambah tenaga pendidik mengingat jumlah pendidik belum memenuhi rasio siswa, karena anak tunagrahita memerlukan pendekatan secara individual.

\section{DAFTAR PUSTAKA}

Al-Qur'an, Al Qur'an dan Terjemahnya, Jakarta, Yayasan Penyelenggara Penterjemah dan Penafsiran Al Qur'an, Departemen Agama RI, 2005.

Creswell, John., Riset Pendidikan; Perencanaan, Pelaksanaan, dan Evaluasi Riset Kualitatif \& Kuantitatif, terj. H. P. Soetjipto\& S. M. Soetjipto, Yogyakarta: Pustaka Pelajar, 2015.

Dacholfany, M. Ihsan., Inisiasi Strategi Manajemen Lembaga Pendidikan Islam Dalam Meningkatkan Mutu Sumber Daya Manusia Islami di Indonesia Dalam Menghadapi Era Globalisasi, Jurnal At-Tajdid, Volume. 1, No. 1 Januari-Juni 2017.

Luddin, A.B.M., Dasar-Dasar Konseling Tinjauan Teori dan Praktik. Bandung: Cipta Pustaka Media, 2010.

Mangunsong, Frieda dkk., Psikologi dan Pendidikan Anak Luar Biasa. Jakarta: Lembaga Pengembangan Sarana Pengukuran dan Pendidikan Psikologi (LPSP3) UI, 1998.

Martasuta, U. D., Mengenal Peserta Didik yang Mengalami GangguanMental. 
Makalah Seminar. Jakarta: UNJ, 2001.

Moleong, L. J., Metode Penelitian Kualitatif.Bandung: PT. Remaja Rosdakarya, 2016.

Mulyana, Deddy., Metodologi Penelitian

Kualitatif. Bandung: PT Remaja Rosdakarya, 2013.

J. W. Santrock, Psikologi Pendidikan,terj. T. Wibowo,Edisi II, Vol. 1. Jakarta: Kencana, 2007.

Sugiyono, Metode Penelitian Kuantitatif, Kualitatif, dan $R \& D$, Bandung: Alfabeta, 2014.

\section{WEB:}

http://ypac-nasional.org/sejarah-ypac/.

http://www.ypac-

semarang.org/index.php?pilih=hal\&id=13 